\title{
Influence of the Zerox Immunostimulant on Cotton Production
}

\author{
Mahbuba Latibovna Ikramova1, Rukhsora Odilovna Atoeva², Dilsora Odilovna Atoeva² \\ ${ }^{1}$ Scientific Research Institute of Crop Breeding, Seeding and Agrotechnology, Bukhara Research Station, \\ Bukhara, Uzbekistan \\ ${ }^{2}$ Bukhara State University, Bukhara, Uzbekistan \\ Email:kumushzokirjonova@mail.ru
}

How to cite this paper: Ikramova, M.L., Atoeva, R.O. and Atoeva, D.O. (2020) Influence of the Zerox Immunostimulant on Cotton Production. American Journal of Plant Sciences, 11, 564-568.

https://doi.org/10.4236/ajps.2020.114041

Received: March 8, 2020

Accepted: April 21, 2020

Published: April 24, 2020

Copyright (C) 2020 by author(s) and Scientific Research Publishing Inc. This work is licensed under the Creative Commons Attribution International License (CC BY 4.0).

http://creativecommons.org/licenses/by/4.0/

\begin{abstract}
In this article, information about universal and triple contact actional ZEROX immunostimulant at 3 various norms and different periods when it affected to Bukhara 10 cotton on 3 numbers of seedlings is presented. Research has shown, when in pre-sowing of seed $2 \mathrm{l} / \mathrm{t}$ and $2 \mathrm{l} / \mathrm{ha}$ in vegetation periods of ZEROX immunostimulant in the number of left seedlings $80-90,000$ plant/ha of Bukhara 10 cotton it was treated, it was determined that the highest yield was obtained.
\end{abstract}

\section{Keywords}

ZEROX Immunostimulant, Bukhara 10, Yield, Three Norms and Different Periods, The Number of Seedlings

\section{Introduction}

One of the most important factors that improve the productivity, quality, growth and development of agricultural crops is to use mineral and local fertilizers [1], as well as, ZEROX $3000 \mathrm{mg} / \mathrm{l}$ silver colloidal immunostimulant which affects in a complex and triple contact action.

The silver colloid ZEROX $3000 \mathrm{mg} / \mathrm{l}$ is used to improve the immune system in plants [2], improve yield and quality [3], and to reduce the effects of abiotic and biotic stresses [4].

Immunostimulants contain the exogenous active substances that regulate working of endogenous hormones. Furthermore, they accelerate the growth of vegetative organs and improve the development of generative organs [5]. Consequently, productivity and cost-effectiveness can be higher than controls [6]. 


\section{Literature Review}

A universal, contact-active ZEROX immunostimulant (containing $3000 \mathrm{mg} / \mathrm{l}$ of silver colloid) has three-way influence on plants.

- Firstly, it destroys fungal and bacterial phytopathogenes.

- Secondly, the silver ions of ZEROX interact with the plant receptors and enzymes, as a result, high levels of oxygen are produced in the plant cell and the immune system against various pathogens in the plant body is formed.

- Thirdly, it regulates effects of endogenous phytohormones in the plant, reduces the sensitivity to ethylene (ripening and aging hormones) and increases the amount of the auxin (growth hormone).

There is some of scientific information about how to use ZEROX $3000 \mathrm{mg} / \mathrm{l}$ silver colloid in plants [2].

The investigation for the prevention of bacterial diseases in potatoes in "in vitro" method has been carried out by Scientists of the University of Gerona in Spain. 3 various norms of ZEROX concentration (1 - $10-100 \mathrm{mg} / \mathrm{l} \mathrm{Ag}$ ions) were obtained, then they were treated at the temperature of $25^{\circ} \mathrm{C}$ in an incubation period of 36 hours. As a result, the concentration of $100 \mathrm{mg} / \mathrm{l} \mathrm{Ag}$ ion was considered as the most appropriate norm of ZEROX immunostimulant. The percentage of loss of phytopathogenic microorganisms was $100 \%$ in this norm [2].

Also in Kazakhstan the ZEROX immunostimulant at 2 1/ha norm was treated 4 times in the treatment of disease bacterial burn in apple plant; as a consequence, Biological effectiveness became 70\% - 91\%. Disease root in papaya, adenium plants was prevented and their dried leaved were restored when 11 of water was added to $10 \mathrm{ml}$ of ZEROX and plants were treated 2 times with the mixture [2].

When Fusariasis and alternariosis disease in potatoes being saved at the temperature of $4^{\circ} \mathrm{C}$ at the end of September were treated with ZEROX (6 ml per 1 litre of water), consequently, it has been determined that diseases of potatoes weren't developed in investigations.

\section{Research Methodology}

In 2018-2019 in Bukhara, In the soil-climatic conditions in CSSEAITI Bukhara SIS Experimental Station, the number of three various seedlings has been left in Bukhara-10 cotton ( $80-90 ; 100-110$; and $120-130$ thousand plant/ha). Then the effect of different norms of ZEROX (1.0 - $2.0-3.0$ 1/ha) on cotton quality and productivity in a field was studied. As an Etalon, Fitovak- $200 \mathrm{ml} / \mathrm{t} \mathrm{immu-}$ nostimulant and as a control variant drinking water were used. Different norms of ZEROX were treated in the vegetation period of cotton.

The experimental area consists of saline soils with a moderate weight of mechanical composition and the ground waters are located in the depth of $2.0-2.5$ $\mathrm{m}$.

All analysis and phenological observations carried out in the investigation in 
field and laboratory condition were conducted on the basis of "Methods experiments of field" which written Uzbekistan Cotton Science Research Institute [7] and Plant Insect Protection Center, as well as, methods given in several other literature. Research data was mathematically processed in the method of B. Dospexov [8].

\section{Analysis and Results}

When ZEROX is treated at different norms and periods with various thickness of Bukhara-10 seedlings, observations about its influences to the cotton's growth and development [9], as well as, yield and fiber quality were conducted. These data are presented in Table 1.

According to the results of Table 1, the best results of the cotton's yield and fiber quality were obtained in the case when the number of left seedlings was in the range of 80 - 90 thousand plant/ha and pre-sowing to cotton seed was treated with ZEROX immunostimulant $2 \mathrm{l} / \mathrm{t}$, fed on leaves at the rate of $2 \mathrm{l}$ /ha during vegetation ( 2 - 4 true leaves, shading and flowering) periods. As a result, additional yield of $5.0 \mathrm{q} /$ ha or $12 \%$, fiber length $1.5 \mathrm{~mm}$, fiber output $2.7 \%$ was of higher rate compared to control.

Table 1. Influence on yield and fiber quality of ZEROX treated at different norms and periods with various thickness of Bukhara-10 seedlings.

\begin{tabular}{|c|c|c|c|c|c|c|c|c|c|c|}
\hline \multirow{2}{*}{$\begin{array}{l}\text { The } \\
\text { number of } \\
\text { seedlings } \\
\text { thousand } \\
\text { plant/ha }\end{array}$} & \multirow{2}{*}{$\begin{array}{c}\text { Norms } \\
\text { treatment } \\
\mathrm{ml} / \mathrm{t} ; \mathrm{ml} / \mathrm{ha} \\
\mathrm{l} / \mathrm{t} ; \mathrm{l} / \mathrm{ha}\end{array}$} & \multirow{2}{*}{$\begin{array}{c}\text { The } \\
\text { number of } \\
\text { shoots in } \\
\text { one cotton, } \\
\text { pcs }\end{array}$} & \multirow{2}{*}{$\begin{array}{l}\text { The } \\
\text { weight of } \\
\text { cotton } \\
\text { from one } \\
\text { shoot, g }\end{array}$} & \multirow{2}{*}{$\begin{array}{c}\text { Fiber } \\
\text { output, \% }\end{array}$} & \multirow{2}{*}{$\begin{array}{l}\text { Fiber } \\
\text { length, } \\
\mathrm{mm}\end{array}$} & \multicolumn{2}{|c|}{$\begin{array}{l}\text { On quality rates, } \\
\text { difference from the } \\
\text { control }\end{array}$} & \multirow{2}{*}{$\begin{array}{l}\text { Average } \\
\text { yield } \\
\text { q/ha }\end{array}$} & \multicolumn{2}{|c|}{$\begin{array}{c}\text { A yield } \\
\text { difference from } \\
\text { the control } \pm\end{array}$} \\
\hline & & & & & & $\%, \pm$ & $\mathrm{mm}, \pm$ & & q/ha & $\%$ \\
\hline \multirow{5}{*}{$80-90$} & 0 & 11.6 & 6.0 & 37.5 & 34.5 & 0.0 & 0.0 & 36.7 & 0.0 & 0.0 \\
\hline & 200 & 14.5 & 7.0 & 40.0 & 35.4 & +2.5 & +0.9 & 39.0 & 2.3 & 5.9 \\
\hline & 1 & 12.8 & 6.5 & 38.5 & 35.0 & +1.0 & +0.5 & 37.7 & 1.0 & 2.7 \\
\hline & 2 & 15.8 & 7.2 & 40.2 & 36.0 & +2.7 & +1.5 & 41.7 & 5.0 & 12.0 \\
\hline & 3 & 15.3 & 7.2 & 40.0 & 35.8 & +2.5 & +1.3 & 41.3 & 4.6 & 11.1 \\
\hline \multirow{5}{*}{$100-110$} & 0 & 11.5 & 6.0 & 37.2 & 34.2 & +0.0 & +0.0 & 35.7 & 0.0 & 0.0 \\
\hline & 200 & 12.8 & 6.5 & 39.4 & 35.1 & +2.2 & +0.9 & 37.3 & 1.6 & 4.3 \\
\hline & 1 & 12.2 & 6.3 & 38.1 & 34.8 & +0.9 & +0.6 & 37.0 & 1.3 & 3.5 \\
\hline & 2 & 15.5 & 7.1 & 39.2 & 35.7 & +2.0 & +1.5 & 40.5 & 4.8 & 11.9 \\
\hline & 3 & 14.1 & 7.1 & 39.0 & 35.4 & +1.8 & +1.2 & 40.3 & 4.6 & 11.4 \\
\hline \multirow{5}{*}{$120-130$} & 0 & 9.2 & 5.5 & 37.2 & 34.1 & +0.0 & +0.0 & 34.7 & 0.0 & 0.0 \\
\hline & 200 & 10.8 & 6.2 & 37.2 & 35.0 & +0.0 & +0.9 & 37.3 & 2.6 & 7.0 \\
\hline & 1 & 10.6 & 6.2 & 37.2 & 34.6 & +0.0 & +0.5 & 36.0 & 1.3 & 3.6 \\
\hline & 2 & 11.8 & 6.9 & 38.4 & 35.6 & +1.2 & +1.5 & 39.0 & 4.3 & 11.0 \\
\hline & 3 & 11.7 & 7.0 & 38.3 & 35.2 & +1.1 & +1.1 & 39.0 & 4.3 & 11.0 \\
\hline
\end{tabular}

$\mathrm{HCP}_{05}=2.27 \% ; \mathrm{HCP}_{05}=1.23 \mathrm{q} / \mathrm{ha}$. 
In the Etalon variant (Fitovak $200 \mathrm{ml} / \mathrm{t} ; 1 / \mathrm{ha}$ ), in the same number of seedlings additional yield of $2.3 \mathrm{q} / \mathrm{ha}$, or $5.9 \%$, with fiber length and $0.9 \mathrm{~mm}-2.5 \%$ compared to control was obtained. The table data show that in the comparison with control, in the variant when ZEROX $21 / t, 1 /$ ha was treated in the number seedling 80 - 90 thousand plants/ha, yield of $2.7 \mathrm{q} / \mathrm{ha}$, fiber length $0.2 \mathrm{~mm}$ and fiber output $0.6 \%$ was higher than the results of etalon.

When the number of left seedlings was 100 - 110 thousand plants/ ha, in the ZEROX 2 1/t, 2 1/ha variant, the additional yield was $4.8 \mathrm{q} / \mathrm{ha}$, or 11.9\%, fiber length and fiber output was $1.5 \mathrm{~mm}-2.0 \%$ higher compared to control. Furthermore, in the research the number of shoots in a single cotton plant and the weight of one shoot were counted; consequently, it was determined that there was a visible difference between variations.

Among the variants being tested, the most appropriate number of seedlings and drug use rates were obtained when ZEROX was treated on $21 / t$ to seed and 2 1/ha of vegetation periods ( 2 - 4 true leaves, shading and flowering) in the number of 80 - 90 thousand plant/ha. According to the results of the average 2 years, it had more than 2.9 shoots and the weight of one shoot was $1.2 \mathrm{~g}$ higher compared to control.

The experimental data shows that when the number of left seedlings was 80 90 thousand plant/ha, ZEROX 2 1/t, 1/ha affects yield and its quality more positively than all other tested options.

It was noted that the yield and quality of the variants in the variants were higher than the control option when ZEROX immunostimulant at $2-31 / t$, and used 2 - 3 1/ha during periods of growth and development on cotton was treated in the number of $80-90,000$ seedlings per hectare. Since, it regulated correctly the action of endogenous phytohormones in the vegetation period of cotton.

When ZEROX is used in cotton, it can be said that it increases levels of auxin and gibberellin, ones of the endogenous phytohormones in plant cells, consequently it can affect positively on yield and its quality [10].

The biosynthesis of fiber formation in these physiological processes includes a complex process that depends on periods, nutrition norms and biotic along with abiotic conditions of the plant.

When bio and immunostimulants are treated in the cotton at exogenous condition, they lead to increase the level of gibberellins that belongs to endogenous phytohormones in the cotton cell. Consequently, this process can affect positively on fiber output, length, micromere index and fiber strength. Such analogical information has been proved through conducting biochemical analysis by foreign and local scientists in their studies [11]. The collected information in our research also confirms their views.

\section{Conclusions}

Thus, the scientific results studied for two years can be summarized as follows: in meadow-alluvial, mechanically heavy structure, saline soil condition of Buk- 
hara, in the number of left seedlings 80 - 90,000 plants per hectare of the Bukhara-10, when in pre-sowing seed $21 / t$ and 2 l/ha of ZEROKS was treated 4 times in the vegetation periods ( 2 - 4 true leaves, shading and flowering) and seed of cotton. It leads to increase levels of auxin and ethylene is related to endogenous phytohormones on the influence of its exogenous hormones (ZEROX $3000 \mathrm{mg} / \mathrm{l}$ silver collide).

As a result:

1) The number of shoots in a single cotton plant was 4.2 per piece;

2) Weight of one shoot was $1.2 \mathrm{~g}$;

3) Additional yield was $5 \mathrm{q} / \mathrm{ha}$ or $12 \%$ the increase was observed in research compared to control.

\section{Conflicts of Interest}

The authors declare no conflicts of interest regarding the publication of this paper.

\section{References}

[1] Ohshiro, M., Akamine, H., Hossain, M.A., Nakamura, I., Tamaki, M. and Nose, A. (2016) Growth Characteristics, Yield and Quality of Some Vegetable Amaranths (Amaranthus spp.) Cultivated in Okinawa, Japan. Japanese Journal of Crop Science, 84, 69-77.

[2] Scientists of Moscow (2016) ZEROX Is Fungicide and Bactericide Contact Action Based on Colloidal Silver. AgroChemProm State University, 15.

[3] Ertani, A., Schiavon, M., Muscolo, A. and Nardi, S. (2013) Alfalfa Plant-Derived Biostimulant Stimulate Short-Term Growth of Salt Stressed Zea mays L. Plants. Plant Soil, 364, 145-158.

[4] Dzung, N.A., Khanh, V.T.P. and Dzung, T.T. (2011) Research on Impact of Chitosan Oligomers on Biophysical Characteristics, Growth, Development and Drought Resistance of Coffee. Carbohydrate Polymers, 84, 751-755.

[5] Cho, M.H., No, H.K. and Prinyawiwatkul, W. (2008) Chitosan Treatments Affect Growth and Selected Quality of Sunflower Sprouts. Journal of Food Science, 73, 70-77. https://doi.org/10.1093/oxfordjournals.jhered.a108085

[6] Jaravin, A. (2019) Drugs That Help Accelerate the Development of Plants and Protect Them from Diseases.

http://www.floraprice.ru/articles/gerbicidy-i-insekticidy/preparatypomogayushchieuskorit-razvitie-rasteniy-i-zashchitit-ikh-ot-bolezney.html 13.11.2019

[7] UzCSRI (2007) Methods of Passing Field Experiments. Toshkent, 147, 3.

[8] Dospexov, B.A. (1989) Methods of Passing Field Experiments. Kolos, Moscow, 42.

[9] Ikramova, M.L. and Atoeva, R.O. (2019) Influence of ZEROX Immunostimulant on the Growth and Development of Cotton. Scientific Herald, 4, 30-37. https://doi.org/10.1104/pp.103.4.1061

[10] Jardin, D.P. (2015) Plant Biostimulants: Definition, Concept, Categories Main and Regulation. Scientia Horticulture, 196, 3-14.

[11] Wang, J., Wang, H., Zhao, P., Han, L., et al. (2010). Over Expression of a Profilin (GhPFN2) Promotes the Progression of Developmental Phases in Cotton Fibers. Plant Cell Physiology, 51, 1276-1290. 